\title{
The correlation between occurrence of dental caries and oral health-related quality of life (OHRQoL) of elderly population in Yogyakarta Special Region
}

\author{
Agustina $D^{1}$, Hanindriyo $L^{2}$, Widita $E^{3}$, Widyaningrum $R^{4}$ \\ ${ }^{1}$ Department of Oral Medicine, ${ }^{2}$ Department of Dental Public Health, ${ }^{3}$ Program Study \\ of Dental Hygiene, ${ }^{4}$ Department of Dentomaxillofacial Radiology, Faculty of Dentistry, \\ Universitas Gadjah Mada, Yogyakarta, Indonesia
}

DOI: http://dx.doi.org/10.19106/JMedSci005002201808

\begin{abstract}
Dental caries is the most common oral disease affecting humans. Based on the Indonesia Basic Health Research (Riskesdas) 2013, prevalence of dental caries in 2013 increased up to $53.2 \%$ from $43.4 \%$ in 2007 . One of the two most increasing prevalence occurred in population of more than 65 years. This disease might affect oral health-related quality of life (OHRQoL) since it causes pain, physical and psychological discomfort. The aim of the study was to evaluate the correlation between occurrence of dental caries and OHRQoL in elderly population in Yogyakarta Special Region. One hundred and eighteen people aged 60 - 80 years consisting 73 female and 45 male involved in the study. The occurrence of dental caries and OHRQoL were determined using decay-missing-filling teeth (DMFT) index, whereas geriatric oral health assessment index (GOHAl) instruments, respectively. The data then were classified into very low, low, moderate and high DMFT and low, moderate and high GOHAl. Spearman's rank correlation test was conducted to determine correlation between occurrence of dental caries and OHRQoL. Mean scores of DMFT index and GOHAl were $16.61 \pm 7.16$ and $47.97 \pm 9.03$, respectively. Very low, low, moderate, and high DMFT index were experienced by $4(3.38 \%), 13(11.02 \%), 25$ $(21.19 \%)$ and $76(64.41 \%)$ of 118 elderly, respectively. Low, moderate and high GOHAl were experienced by $71(60.17 \%), 25(21.19 \%)$ and $22(18.64 \%)$ of 118 elderly, respectively. Spearman's rank correlation test showed that the correlation coefficient (r) was $-0.263(p=0.004)$. There is a negative moderate significant correlation between the occurrence of dental caries and OHRQoL of elderly population in Yogyakarta Special Region.
\end{abstract}

\section{ABSTRAK}

Karies gigi merupakan penyakit mulut yang paling sering mengenai manusia. Berdasarkan data riset kesehatan dasar (Riskesdas) 2013, prevalensi karies gigi di Indonesia tahun 2013 meningkat sampai $53,2 \%$ dari $43,4 \%$ tahun 2007. Peningkatan prevalensi antara lain terjadi pada populasi berumur lebih dari 65 tahun. Penyakit ini kemungkinan akan mempengaruhi kualitas hidup terkait kesehatan mulut karena karies gigi menyebabkan nyeri, ketidaknyamanan fisik dan psikologis. Penelitian ini bertujuan mengkaji hubungan antara kejadian karies gigi dengan kualitas hidup terkait kesehatan mulut pada populasi lanjut usia di Daerah Istimewa Yogyakarta (DIY). Seratus delapan belas penduduk berumur 60-84 tahun terdiri dari 73 wanita dan 45 laki-laki terlibat dalam penelitian ini.

\footnotetext{
* corresponding author : dewi_agustina_fkg@ugm.ac.id
} 
Kejadian karies gigi dan kualitas hidup terkait kesehatan mulut masing-masing ditentukan menggunakan indeks decay-missing-filling teeth (DMFT) dan geriatric oral health assessment index (GOHAl). Data yang diperoleh kemudian diklasifikasikan menjadi DMFT sangat rendah, rendah, sedang dan tinggi serta GOHAl rendah, sedang dan tinggi. Uji korelasi Spearman dilakukan untuk menentukan korelasi antara kejadian karies gigi dengan kualitas hidup terkait kesehatan mulut. Rerata indeks DMFT dan GOHAI masing-masing yaitu 16,61 $\pm 7,16$ dan 47,97 \pm 9,03. Indeks DMFT sangat rendah, rendah, sedang dan tinggi masing-masing dialami oleh 4 (3,38\%), $13(11,02 \%), 25(21,19 \%)$ dan 76 $(64,41 \%)$ dari 118 lansia. GOHAl rendah, sedang dan tinggi masing-masing dialami oleh $71(60,17 \%), 25(21,19 \%)$ dan $22(18,64 \%)$ dari 118 lansia. Hasil uji korelasi Spearman menunjukkan bahwa koefisien korelasi ( $r$ ) yaitu -0,263 ( $p=0,004)$. Dapat disimpulkan terdapat korelasi negatif signifikan sedang antara kejadian karies gigi dengan kualitas hidup terkait kesehatan mulut pada populasi lanjut usia di DIY.

Keywords: Correlation - DMFT - GOHAI - OHRQoL - elderly

\section{INTRODUCTION}

Despite advancements in oral disease science, dental caries continues to be a worldwide health concern, affecting humans of all ages. Approximately 2.3 billion (32\%) people have dental caries in their permanent teeth worlwide. ${ }^{1}$ Dental caries is one of the most common infectious diseases linked to bacteria in the dental plaque overlying the dental hard tissue. Although acid generating bacteria are the etiologic agents, dental caries has been thought of as multifactorial. It is influenced by dietary and host factors as well. In addition, the role of saliva as a defense system against dental caries is well documented. These defense systems include clearance, buffering, antimicrobial agents, and calcium and phosphate delivery for remineralization. ${ }^{2}$

The first and most common symptom of dental caries is toothache. This is typically an infection or irritation of the tooth pulp usually causes the pain. Tooth pain or achy feeling, particularly after sweet, hot, or cold foods and drinks are first indicator. If dental caries is more severe, it can cause eating difficulty. ${ }^{3}$ Dental caries can also cause bad breath. ${ }^{4}$ In highly progressed cases, an infection can spread from the tooth to the surrounding soft tissues. Complications may include inflammation of the tissue around the tooth, tooth loss, and infection or abscess formation. ${ }^{3}$ The earliest sign of a new carious lesion is the appearance of a chalky white spot on the surface of the tooth, indicating an area of demineralization of enamel. Visible pits or holes in the teeth are strong positive indicator of tooth decay. ${ }^{2}$ Recently, health is defined by a complete physical, mental and social well-being, not merely the absence of disease. Thereby the quality of life of a patient is taken into account. Oral health-related quality of life (OHRQoL) is defined as a multidimensional construct that reflects people's comfort when eating, sleeping, and engaging in social interaction; their self-esteem; and their satisfaction with respect to their oral health. ${ }^{5}$ The OHRQoL is usually assessed by studying how factors such as function, pain, psychological, and social aspects affect the well-being of an individual. ${ }^{6}$ Oral health-related quality of life is a more holistic approach in health care, in order to improve the oral related satisfaction and quality of life of patients, and not merely the eradication of disease. ${ }^{7}$

There has been a significant increase of elderly population in recent years. About $80 \%$ 
of elderly worldwide is found in developing countries. ${ }^{8}$ World Health Organization (WHO) predicted that the population of elderly in Indonesia will reach $11.34 \%$ or 28.8 million people in 2020. ${ }^{9}$ Amongst 33 provinces in Indonesia, Yogyakarta Special Province is a province with the highest number of elderly that reaches up to $14.02 \%$ in 2010 . Moreover, Yogyakarta Special Province is a province with the longest life expectancy as well i.e. up to 74.2 years in 2010 and will be predicted up to 75.5 years in $2035 . .^{10}$ The longer life expectancy of population in Yogyakarta Special Province is contributed by following factors : (i) comfortable environment; (ii) very good social support for elderly activities; (iii) very good community care; (iv) a relative cheap of life expenditure; (v) adequate health care facilities for elderly; (iv) accessible health care facilities. ${ }^{11}$

Health problem of elderly varies as consequences of physiologic or pathologic processes. Becoming old someone prones to chronic diseases and acute infections. This condition is deteriorated by decreasing immune system in elderly. Elderly at least have one chronic medical disturbance, so increasing elderly population might increase percentage of chronic diseases as well. ${ }^{12}$ It is common that polymedication is experienced by elderly. Majority of elderly at least is taking one prescribed medication. ${ }^{13}$ Polypathology and polymedication result from aging and disease processes. Medication for systemic diseases and systemic disease itself in elderly might cause hyposalivation either with or without xerostomia. It has been reported that $80 \%$ of prescribed medication cause xerostomia. ${ }^{14}$

On the other hand, oral health and function deteriorate as long as getting older. ${ }^{15}$ Poor oral health in elders is caused by edentulism, dental caries, periodontal disease, xerostomia, dysfunction of salivary gland and oral mucosal lesion including oral precancer. ${ }^{8}$ All these findings may give badly impact for daily life of elderly that results in decreasing of oral function, self confidence and social life that eventually affect OHRQoL. Indonesia Basic Health Research (Riskesdas) 2013 reported that the prevalence of dental caries in Indonesia increased up to $53.2 \%$ in 2013 from $43.4 \%$ in 2007 . One of the two most increasing prevalence occurred in population of more than 65 years. ${ }^{16}$ The aim of this study was to investigate the correlation between occurrence of dental caries and OHRQoL of elderly population in Yogyakarta Special Region.

\section{MATERIALS AND METHODS}

Participants

This was an observational communitybased cross sectional study involving a total of 118 elderly aged 60-84 years consist of 45 males and 73 females. Participants were recruited randomly from six community health station for elderly (Posyandu Lansia) i.e from three representative urban area (Wirobrajan, Sewon, Minomartani) and three representative rural area (Pundong, Moyudan, Berbah) of Yogyakarta Special Region. The characteristics of rural and urban area was determined based on the criteria published by the Indonesian National Board of Statistics in 2010. A scoring technique which corresponds with the population density, proportion of agricultural-related profession, and the existence of public-leisure facilities was used to establish the criterion. ${ }^{10}$ Written informed consent was obtained from all participants following after receive explanation concerning the goal, the significance, and the course of the study. The protocol of the study has been approved by the Medical and Health Research Ethics Committee (MHREC), Faculty of 
Medicine, Universitas Gadjah Mada and Dr. Sardjito General Hospital, Yogyakarta (KE/ FK/441/EC/2016).

\section{Procedure}

The subjects were conducted clinical intraoral examination to determine DMFT index (the total number of decayed/D, missing/ $\mathrm{M}$ and filled/F permanent teeth in an individual) using dental diagnostic instrument. Intraoral examination was carried out by four trained dentists under sufficient illumination with artificial light. Dentition status to measure the DMFT was examined using the procedures guided by the WHO Basic Oral Health Survey 2013 method. The examiners were calibrated before and during the survey, and inter-examiner reliability was assessed. According to replicated examinations of 10 patients, the Kappa value ranged from 0.75 to 0.9 which corresponds with substantial to almost perfect agreement according to the WHO Basic Oral Health Survey Method. ${ }^{17}$

The classification of DMFT index was very low $(<5.0)$, low (5.0-8.9), moderate (9.013.9), and high (>13.9). The maximum score of DMFT index is 32 whereby a higher score indicates a more prevalence of dental caries. ${ }^{17}$

Oral health-related quality of life was determined using GOHAI. The 12-item questionnaire of GOHAI was developed to assess three dimensions of OHRQoL i.e. physical function, pain or discomfort and psychosocial function. It consists of a six point Likert scale from never, seldom, sometimes, often, very often and always with the score ranging from 0 to 5 . The final score ranges from 0 to 60 whereby a higher score indicates a better OHRQoL. The classification of GOHAI score was high (57-60), moderate (51-56) and low $(\leq 50)$. The higher score of GOHAI the better OHRQoL. ${ }^{18}$

\section{Statistical analysis}

Spearman's rank correlation test using software of SPSS of 16.0 version was applied to evaluate the correlation between occurrence of dental caries and OHRQoL.

\section{RESULTS}

Clinical intraoral examination to determine DMFT index was conducted to all subjects using dental diagnostic instrument. The results are presented in TABLE 1 . Mean of DMFT index for all subjects was $16.61 \pm$ 7.16 ranging from 2 to 32 .

TABLE 1. Result of DMFT index $(n=118)$

\begin{tabular}{llcc}
\hline $\begin{array}{c}\text { DMFT } \\
\text { index }\end{array}$ & Classification & $\begin{array}{c}\text { Number } \\
\text { of subjects }\end{array}$ & $\begin{array}{c}\text { Percentage } \\
(\%)\end{array}$ \\
\hline$<5.0$ & Very low & 4 & 3.38 \\
$5.0-8.9$ & Low & 13 & 11.02 \\
$9.0-13.9$ & Moderate & 25 & 21.19 \\
$>13.9$ & High & 76 & 64.41 \\
\hline
\end{tabular}

Oral health-related quality of life was determined based on GOHAI score as demonstrated on TABLE 2. Mean of GOHAI score was $47.97 \pm 9.03$ ranging from 5 to 60 .

TABLE 2. Result of OHRQoL based on GOHAI measurement $(n=118)$

\begin{tabular}{llcc}
\hline $\begin{array}{c}\text { GOHAI } \\
\text { score }\end{array}$ & Classification & $\begin{array}{c}\text { Number } \\
\text { of subjects }\end{array}$ & $\begin{array}{c}\text { Percentage } \\
(\mathbf{\%})\end{array}$ \\
\hline$\leq 50$ & Low & 71 & 60.17 \\
$51-56$ & Moderate & 25 & 21.19 \\
$57-60$ & High & 22 & 18.64 \\
\hline
\end{tabular}

Statistical analysis showed that the correlation coefficient (r) was -0.265 with $\mathrm{p}=0.004$. It was indicated that there is a negative moderate significant correlation between the occurrence of dental caries and OHRQoL of elderly population in Yogyakarta Special Region. 


\section{DISCUSSION}

Result of DMFT index showed that majority of subjects (64.41\%) had high DMFT index $(\geq 13.9)$ with the mean was 16.61. This mean was much higher than the mean of DMFT index in New Delhi's elderly that was 13.8 from total of 452 participants. ${ }^{19}$ On the other hand, from Srivastava et al.'s study in New Delhi as well, found that the mean of DMFT index in persons aged $\geq 60$ years during 2006-2010 was 14.4. from total of 448 subjects. ${ }^{20}$ The mean of DMFT in this study was higher than that in Northeast China i.e. $13.9 .{ }^{21}$ On the other hand, dental caries prevalence among the elderly in Norway was 25.4 of 582 subjects. ${ }^{22}$ According to Riskesdas prevalence of dental caries in Indonesia in 2013 increased up to $53.2 \%$ compared to $43.4 \%$ in $2007 .{ }^{16}$ The two most increasing prevalence occurred in population of more than 65 years and in children of 12 years. The increasing prevalence occurred in persons $\geq 65$ years was up to $14.3 \%$ compared to that of the children of 12 years that was $13.7 \%$.

Oral and dental disease is the most disease suffered by people with the prevalence up to $61 \%$. Dental caries and periodontal (tooth supporting tissue) disease was the two most oral and dental diseases experienced by Indonesian population. ${ }^{16}$ These diseases are caused by dental plaque (biofilm) as a result of poor oral hygiene which leads to bacteria spreading across the tooth's surface. Biofilm accumulates in the oral cavity causes dental caries and periodontitis. ${ }^{23}$

Only a few countries appear to have national data on oral hygiene habits among older people. Tooth brushing remains the most popular oral hygiene practice worldwide. However, according to the country reports this practice is less frequent in developing countries than in developed countries. Meanwhile, traditional oral self-care by use of chew sticks or powder is common in developing countries. Within regions, substantial variation is reported in the percentage of older people performing regular oral hygiene. ${ }^{24}$

Aging is a natural and progressive process capable of producing limitations and changes in the functioning of the body making the individual more vulnerable and susceptible to chronic diseases such as osteoarthritis, osteoporosis, Parkinson's disease. ${ }^{25}$ Severity of osteoarthritis in the hands is correlated with impaired functional ability resulting in unable to maintain proper oral hygiene that leads to plaque accumulation which increases the likehood of dental caries. ${ }^{26,27}$ Parkinson's disease is characterized by dementia and loss of cognitive abilities. ${ }^{28}$ Due to loss of cognitive function patients having difficulties to memorize oral hygiene practice. Besides that, in the early stages patients may present the inability to perform functions and their motor skills that makes patients have difficulty to maintain the oral health care. ${ }^{29}$

Other oral problem that commonly experienced by elderly is xerostomia. Xerostomia is subjective feeling of dry mouth either accompanied with hyposalivation (saliva secretion per minute $<0.1 \mathrm{~mL}$ ) or not. $^{30}$ It is estimated that about $30 \%$ of the population older than 65 suffer from xerostomia. ${ }^{31}$ Medications and systemic disease are aggravating factors that contribute to xerostomia in the elderly. ${ }^{32}$ Xerostomia has a variety of possible causes. In recent years, the most common cause of xerostomia is medications. Xerostomia has been associated with more than 500 medications. Xerostomia can be caused by many factors such as diseases, medications, complications of radiationtherapy or chemotherapy, dehydration, psychological conditions such as anxiety and stress, complication of chronic graft-versus host disease (cGVHD), malnutrition and 
mouth breathing. ${ }^{33,34}$ Xerostomia-associated diseases could be Sjogren Syndrome, sarcoidosis, diabetes mellitus, primary biliary cirrhosis, rheumatoid arthritis, stroke, Alzheimer's, depression, and chronic anxiety. Some medication that can cause xerogenic effects such as analgesics, antianxiety/ sedative/hypnotics, anticonvulsants, antidepressants, antihypertensives, antihistamines, bronchodilators, diuretics, gastrointestinal drugs, antispasmodics, cytotoxic drugs, skeletal muscle relaxants. ${ }^{34-36}$ Patient with hyposalivation or xerostomia also are susceptible to oral infection including candidiasis, dental caries, periodontal disease and tooth loss. ${ }^{37}$ Without enough saliva, oral environment cannot be maintained in optimal $\mathrm{pH}$, so the mouth is colonized rapidly with cariogenic bacteria and oral self-cleansing cannot be implemented that causes bad oral hygiene $^{33}$, in turn, someone will be more susceptible having dental caries. So, the high prevalence of dental caries in this study might be contributed as well by medications consumed and diseases experienced by the subjects. In this study 19 subjects consumed antihypertensives, 8 subjects consumed analgesics/anti-inflammatory medications. Six subjects consumed antihistamines and 5 subjects consumed gastrointestinal drugs. Besides that, it was detected that 8 subjects suffered from diabetes mellitus. Osteoarthritis, rheumatoid arthritis and stroke, each was also experienced by one subject. Another cause of dental caries is poor oral hygiene since the biofilm will more accumulated in oral cavity. In this study, 51 of 118 subjects (43.22\%) had poor oral hygiene that made them prone experiencing dental caries.

It was clear that majority of elderly $(60.17 \%)$ had low OHRQoL that might be caused by poor oral health condition (TABLE 2). This findings supported the statements that deterioration of oral health and function go along with the increasing age of people. ${ }^{15}$ From this result it seemed that the care towards oral health was still low in elderly in which this condition was probably influenced also by ageism concept that was believed by almost all elderly. ${ }^{38}$ In this concept, elderly believes that deterioration of oral condition was natural process and occurs for all elderly, so it makes elderly having less effort to improve their oral condition.

To assess OHRQoL in this study was something so difficult since concept of quality of life is elusive and abstract. Quality of life can be intuitively understood however, it is very difficult to be defined. Perception of quality of life is influenced by many factors such as socio-economic condition, level of education, cultural, political, practical contexts in where the quality of life is implemented and measured. ${ }^{39}$

According to the result of Spearman's rank correlation test showed that there was a negative moderate significant correlation between the occurrence of dental caries and OHRQoL of elderly population in Yogyakarta Special Region. A negative correlation between the occurrence of dental caries and OHRQoL indicates that an increase score of DMFT index will bring a decline in the OHRQoL. The negative moderate significant correlation meant the more dental caries the more impact on GOHAI score by decreasing the OHRQoL. Or it can be said that the higher score of DMFT, the lower the OHRQoL of the elderly population in Yogyakarta Special Region.

As stated above, person with dental caries will have a symptom of pain. The pain is getting severe along with the more progressive caries process. When the enamel and dentin are destroyed, the cavity becomes more noticeable. Once the decay passes through 
enamel, the dentinal tubules, which have passages to the nerve of the tooth, become exposed, resulting in pain that can be transient, temporarily worsening with exposure to heat, cold, or sweet foods and drinks. When the decay has progressed enough to allow the bacteria to overwhelm the pulp tissue in the center of the tooth, a toothache can result and the pain will become more constant. ${ }^{3}$

By understanding the chronological process of tooth decay, it was clear that dental caries will cause pain and the pain will influence the GOHAI assessment. There was three dimensions of OHRQoL i.e. physical function, pain or discomfort and psychosocial function that was assessed in GOHAI. If the dental caries was still untreated, the dental pulp will be non vital, and then the infection will spread to the periodontal tissue causing of tender to pressure. The latter will result in eating difficulty that was associated with the oral dysfunction. Dental caries becomes area of focal infection if still untreated. And it has to be extracted to prevent the spreading of the infection. Dental caries and periodontal disease is the two most oral disease that cause tooth loss. Tooth loss will impair mastication function of oral tissue. Unrehabilitated tooth loss may influence psychological condition of someone. On the other hand, dental caries can also cause bad breath that may decrease self convidence of someone. ${ }^{4}$ In the psychosocial aspect, speech and eating difficulties can impair social interactions which may cause some patients to avoid social engagements where it affects the OHRQoL. ${ }^{31}$ Social interactions may also be affected due to a decreased selfesteem caused by difficulties in speech and mastication. ${ }^{40}$ All of those impacts of dental caries in turn affect OHRQoL negatively.

This is the first study conducted in Yogyakarta Special Region to correlate the occurrence of dental caries and OHRQoL in elderly population. The results of this study might be considered by Indonesian government especially in Yogyakarta Special Region to plan the better oral health management for elderly, in turn, it can increase OHRQoL. To improve the oral health or to reduce the occurrence of dental caries in elderly requires inter-professional collaboration of health personnel since dental caries is a multifactorial disease modulated by many aspects of health and behavior not only oral ecology.

Finally, the limitations of our study should be taken into consideration. The exact mechanism of this relationship was not clarified in this study and it needs to be further explored in longitudinal studies. Since this study was a cross sectional, which was conducted on modest sample size of 118 subjects, study with larger sample sizes needs to be carried out in the future to endorse the results observed in our study. Future work with larger, more diverse populations and more complete information would be essential to complete our findings. Furthermore, as the nature of the sample size used in this study, the result generalisability might not be completely dependable.

\section{CONCLUSIONS}

In conclusion, there is a negative moderate significant correlation between the occurrence of dental caries and OHRQoL of elderly population in Yogyakarta Special Region. The higher score of DMFT, the lower the OHRQoL is observed in elderly population.

\section{ACKNOWLEDGEMENTS}

The authors declare that they have no conflict of interests. This study was supported by a Research Grant from the Indonesian Ministry of Research, Technology and Higher 
Education under the scheme of Excellence Higher Education Institution Research in 2016. We are profoundly grateful to the study participants for their assistance.

\section{REFERENCES}

1. Global Burden of Disease 2015 Disease and Injury Incidence and Prevalence, Collaborators. Global, regional, and national incidence, prevalence, and years lived with disability for 310 diseases and injuries, 19902015: a systematic analysis for the Global Burden of Disease Study 2015. Lancet 2015; 388 (10053): 1545-602.

2. Hurlbutt M, Novy B, Young D. Dental caries : a pH-mediated disease. CDHA Journal. 2010; 25(1) : 9-14.

3. Laudenbach, JM, Simon, Z. Common dental and periodontal diseases: evaluation and management. Med Clin North Am 2014; 98 (6): 1239-60.

http://dx.doi: 10.1016/j.mcna.2014.08.002.

4. Saini N, Ajwani P, Kaur K, Kumar A. Oral malodor : a common oral problem. J Bioeng Biomed Sci 2011; 2(1) : 1-7. http://dx.doi: 10.4172/2155-9538.1000108

5. US Department of Health and Human Services. Oral health in America: a report of the surgeon general. Rockville, MD: US Department Health and Human Services, National Institute of Dental and Craniofacial Research, National Institute of Health. 2000.

6. Bennadi D \& Reddy CVK. Oral health related quality of life, J Int Soc Prev Community Dent 2013; 13(1):1-6. http://dx.doi: 10.4103/2231-0762.115700

7. Hebling E \& Pereira AC. Oral healthrelated quality of life : a critical appraisal of assessment tools used in elderly people. Gerodontology 2007; 24: 151-61.

http://dx.doi:

$10.1111 / \mathrm{j} .1741-$ 2358.2007.00178.x
8. Petersen PE \& Yamamoto T. Improving the oral health of older people: the approach of the WHO Global Oral Health Programme. Community Dent Oral Epidemiol 2005; 33: 81-92.

h t t p://dx.doi: $10.1111 /$ j. 1600 0528.2004.00219.x

9. Komisi Nasional Lanjut Usia. Profil penduduk lanjut usia. Jakarta: Komisi Nasional Lanjut Usia, 2010.

10. Badan Pusat Statistik. Statistik penduduk lanjut usia. Jakarta: Badan Pust Statistik, 2010.

11. Dinas Kesehatan Provinsi DIY. Profil kesehatan Provinsi DIY tahun 2013. Yogyakara: Pemerintah Provinsi DIY, 2013.

12. Little JW, Falace DA, Miller CS, Rhodus NL. Dental management of medically compromised patient. $6^{\text {th }}$ ed. Missouri: Mosby, Inc., St Louis, Missouri, 2002.

13. Chrischilles EA, Foley DJ, Wallace RB, Lemke JH, Semla TP, Hanlon JT. Use of medications by persons 65 and over : data from the established populations for epidemiologic studies of the elderly. J Gerontol 1992; 47(5):M137-44. https://doi.org/10.1093/geronj/47.5.M137

14. Sreebny LM \& Schwartz SS. A reference guide to drugs and dry mouth, $2^{\text {nd }}$ ed. Gerodontology 1997;14(1): 33-47. https://doi.org/10.1111/j.17412358.1997.00033.x

15. Greenberg MS \& Glick M. Burket's oral medicine, $10^{\text {th }}$ ed. Ontaria: B.C. Decker Inc., 2003.

16. Badan Penelitian dan Pengembangan Kesehatan, Kementerian Kesehatan RI. Riset kesehatan dasar 2013. Jakarta: Kementerian Kesehatan RI, 2013.

17. World Health Orgnization. Oral health survey: basic method, $5^{\text {th }}$ ed. Geneva: World Health Organization, 2013.

18. Atchison KA \& Dolan TA. Development of the geriatric oral health assessment index, $\mathrm{J}$ Dent Educ 1990; 54(11):680-7. 
Agustina D. et al., The correlation between occurrence of dental caries and oral health-related quality of life (OHRQoL) of elderly population in Yogyakarta Special Region

19. Patro BK, Kumar BR, Goswami A, Mathur VP, Nongkynrih B. Prevalence of dental caries among adults and elderly in an urban resettlement colony of New Delhi. Indian J Dent Res 2008; 19(2): 95-8. https://doi.org/10.4103/0970-9290.40460

20. Srivastava R, Gupta SK, Mathur VP, Goswami A, Nongkynrih B. Prevalence of dental caries and periodontal diseases, and their association with socio-demographic risk factors among older persons in Delhi, India: a community -based study. Southeast Asian J Trop Med Public Health 2013; 44(3):523-33.

21. Liu L, Zhang Y, Wu W, Cheng M, Li Y, Cheng R. Prevalence and correlates of dental caries in an elderly population in Northeast China. PLOS-One 2013;8(11):1-6. https://doi.org/10.1371/journal.pone.0078723

22. Henriksen BM, Ambjørnsen E, Axell T. Dental caries among the elderly in Norway. Acta Odontol Scand 2004; 62(2):75-81. https://doi.org/10.1080/00016350310008580

23. Gurenlian JAR. The role of dental plaque biofilm in oral health. J Dent Hyg 2007; 81 (5):1-11.

24. Petersen PE, Kandelman D, Arpin S and Ogawa H. Global oral health of older peoplecall for public health action. Community Dent Health. 2010; (Suppl 2):257- 68.

25. Kelsey JL \& Lamster IB. Influence of musculoskeletal conditions on oral health among older adults. Am J Public Health. 2008; 98(7):1177-83.

https://doi.org/10.2105/AJPH.2007.129429

26. El-Sherif HE, Kamal R, Moawyah O. Hand osteoarthritis and bone mineral density in postmenopausal women; clinical relevance to hand function, pain and disability. Osteoarthritis Cartilage 2008;16:12-7. https://doi.org/10.1016/j.joca.2007.05.011

27. Pokrajac-Zirojevic V, Slack-Smith LM, Booth D. Arthritis and use of dental services: a population based study. Aust Dent J 2002;47:208-13.

https://doi.org/10.1111/j.1834-7819.2002. tb00330.x

28. Nascimento N, Albuquerque D. Evaluation of functional changes in the evolutionary stages of Parkinson's disease : a case series. Fisioter Mov 2005; 28(4):741-9. https://doi.org/10.1590/0103-5150.028.004. AO11

29. Batista LM, Portela de Oliveira MT, Magalhaes WB, Bastos PL. Oral hygiene in patients with Parkinson's disease. RI Med J 2015; 98(11): 35-7.

30. Chiappin S, Antonelli G, Gatti R, De Palo EF. Saliva specimen: a new laboratory tool for diagnostic and basic investigation. Clin Chim Acta 2007; 383(1-2):30-40. https://doi.org/10.1016/j.cca.2007.04.011

31. Ship JA, Pillemer SR, Baum BJ. Xerostomia and the geriatric patient. J Am Geriatr Soc 2002; 50(3):535-43.

https://doi.org/10.1046/j.15325415.2002.50123.x

32. Shetty SR, Bhowmick S, Castelino R and Babu S. Drug induced xerostomia in elderly individuals: An institutional study. Contemp Clin Dent 2012; 3(2):173-5.

33. Turner M \& Ship JA. Dry mouth and its effects on the oral health of elderly people. JADA 2007; 137:15S-20S.

34. Sultana N \& Sham ME. Xerostomia : an overview. Int J Dent Clin 2011; 3(2):58-61.

35. Friedman PK. Geriatric dentistry: caring for our aging population. $1^{\text {st }}$ ed. Iowa: John Wiley \& Sons, Inc., 2014.

36. Scully C. Drug effects on salivary glands: dry mouth. Oral Dis 2003; 10(9):165-76.

https://doi.org/10.1034/j.16010825.2003.03967.x

37. Gupta A, Epstein JB, Sroussi H. Hyposalivation in elderly patients, pratique clinique. JADC 2006; 72(9):841-6. 
38. Iversen TN, Larsen L, Solem PE. A conceptual analysis of ageism. Nordic Psychol 2009; 61: 4-22.

https://doi.org/10.1027/1901-2276.61.3.4

39. Locker D. Concepts of oral health, disease and the quality of life. In: Slade GD editor, Measuring oral health and quality of life. North Carolina: Department of Dental Ecology, School of Dentistry, University of North Carolina, 1997.
40. Folke S, Paulsson G, Fridlund B and Söderfeldt B. The subjective meaning of xerostomia-an aggravating misery. Int J Qual Stud Health Well-being 2009; 4:245-55. https://doi.org/10.3109/17482620903189476 https://doi.org/10.3402/qhw.v4i4.5020 